\title{
Women entrepreneurship in the rural informal sector
}

\author{
Rekhapriyadharshini A* and Reeves Wesley J \\ VIT Business School, VIT University, India
}

\begin{abstract}
This study investigated the reason behind the rural women entering into entrepreneurship and the challenges faced by them. A qualitative study has been done with 21 rural women entrepreneurs who are doing entrepreneurship in the informal sector. The findings reveal that rural women enter into entrepreneurship due to some external circumstances such as divorce, widow or gender discrimination. They are using entrepreneurship as a coping strategy to overcome their problems. This study will be admissible in present scenario.
\end{abstract}

Keywords: Women entrepreneurship; Rural informal sector.

\section{Introduction}

Informal sector constitutes an important part of Indian economy. In 1972, the term informal sector was first used by the International labor organization (ILO) to denote a wide range of small and unregistered economic activities. The informal sector may be defined as those establishments that employ less than 10 persons with or without use of power. The informal sector consists of all activities that fall outside the formal net registered, taxed, licensed, statistically documented, and approximately zoned business enterprises (Thomas, 1988). ILO defines informal sector as "enterprises with a small scale of operation, family ownership, laborintensive units, adaptive technology and operating in unregulated and competitive markets". The National commission on Enterprises in unorganized sector (NCEUS) defines the informal sector consists of all unincorporated private enterprises owned by individuals or households engaged in the sales and production of goods and services operated on a proprietary or partnership basis with less than ten total workers. Around 86\% of employees were working in the informal sector as of 2004-2005 in India (NCEUS 2008).

In most developing countries women are the active players in the informal sector (Mbeche, 2002). Despite all social hurdles, many women have been successful in their works. Women entrepreneurs are found in all countries and contribute more and more to the global economy (Bosma and Harding, 2006). Until now, a widespread assumption has been that such women engaged in informal entrepreneurship are necessityentrepreneurs engaged in low-paid, menial, exploitative work in the absence of alternative means of livelihood (Chen et al.2004; ILO 2002a).

It is estimated that presently women entrepreneurs account for about $10 \%$ of the total entrepreneurs in India (Barhate, 2012).Entrepreneurship is traditionally considered to be a male dominated pursuit, but the number of women entering entrepreneurship is increasing comparatively. They have multiple roles and responsibilities in their family and also in their business. Today, the term "entrepreneur" is no longer dominated by males. In $21^{\text {st }}$ century, the autonomy and power of woman have become more obvious and as clear (Purdy 2005).Over the last century, women have substantially infiltrated professional, educational, managerial and executive positions once employed by men (Eisenberg, 2010). An entrepreneur has been dominated or pursuit by men, but many women are stepped into the entrepreneurship today. The field of entrepreneurship is increasing its theoretical focus on the unique contributions of women entrepreneurs to business and society (de Bruin, Brush and Welter, 2007). Nowadays, women are not only independent but also have their autonomy in many aspects such as politics, education, socially and economically. They have the liberty of expressing their own ideas and displeasures on a variety of matters (Brindley, 2005). This article intended to find out the reasons for rural women entering into entrepreneurship.

\section{Women entrepreneurship}

Women entrepreneurship may be defined as "women achieving economic independency and generates employment opportunities to others by running an enterprise".In the past fifty years, society shifted their perspectives of women being primarily child bearers and caregivers to include primary breadwinners or cocontributors to the family income (Parker, 2009). Too often, entrepreneurial efforts by women have gone unnoticed, and their contributions have been underappreciated. Lack of recognition or attention, however, does not negate either the significant contribution women's entrepreneurial efforts have had on wealth creation in economies around the globe (de Bruin, Brush and Welter, 2006). Women entrepreneurs in MSEs are the engine of growth and plays important role in poverty reduction in developing countries (World Bank report, 2003). 


\section{Methods}

The data were collected in the villages around Vellore district. In this study, 21 rural women entrepreneurs were interviewed directly and recorded by the researcher. Those women were engaged in various business like vegetable vendor (4 respondents), flower vendor (5 respondents), petty shop (4 respondents), dairy products (3 respondents), tailoring (1 respondent), beauty parlor (1 respondent) and food products (3 respondents). The average age of the respondent is 35 .

\section{Results and Discussion}

The reason behind women in rural areas to embark entrepreneurship may vary. Some are engaged in entrepreneurship due to external circumstances such as divorce, widow or gender discrimination, some entering into entrepreneurship in order to overcome their poverty, unemployment or loss of family support.As a coping strategy it has become necessary for those women to work in the informal sector to be the bread winners or to support their family income.

Table: 1

\begin{tabular}{|c|c|c|c|}
\hline Type of work & External factors & Self-employment\& career & Family business \\
\hline Vegetable vendor & 3 & 1 & - \\
\hline Flower vendor & 4 & 1 & 2 \\
\hline Petty shop & 2 & - & - \\
\hline Dairy products & 3 & - & - \\
\hline Tailoring & - & 1 & - \\
\hline Beauty parlor & - & - & 2 \\
\hline Food products & 1 & $\mathbf{2}$ & $\mathbf{2}$ \\
\hline Rank & $\mathbf{1}$ & & - \\
\hline
\end{tabular}

Table 1 show that around $62 \%$ of women entering into entrepreneurship due to their external circumstances such as divorce, widow or conflict within their family and is considered to be the major reason for rural women entering into entrepreneurship, only $19 \%$ are entering for their career, and remaining $19 \%$ women entering for self-employment\& Career and family business.

\section{Challenges faced byrural women entrepreneurs}

There are several factors that act as a barrier for rural women entering into entrepreneurship. The problem ranges from improper infrastructure, mobilizing, capital, labor, marketing, family and personal obligations, male chauvinism, work-family conflict and lack of awareness about financial assistance, loan facilities and schemes.

Table: 2

\begin{tabular}{|cl|c|c|}
\hline $\begin{array}{c}\text { Problems faced by rural women } \\
\text { entrepreneurs }\end{array}$ & Number of respondents & Rank \\
\hline 1. & Lack of proper infrastructure & 15 & $\mathbf{3}$ \\
\hline 2. & Lack of awareness & 9 & $\mathbf{6}$ \\
\hline 3. & Lack of mobility & 18 & $\mathbf{2}$ \\
\hline 4. & Lack of capital investment & 17 & $\mathbf{5}$ \\
\hline 5. & Work -Family conflict & 11 & $\mathbf{4}$ \\
\hline 6. & Lack of financial assistance & 14 & $\mathbf{7}$ \\
\hline 7. & Lack of family support & 5 & \\
\hline
\end{tabular}

From table 2, it is shown that $81 \%$ of rural women entrepreneurs are finding problem in capital investment for their business, $71 \%$ of respondents are not having proper infrastructure, $43 \%$ of rural women entrepreneurs are unaware of loan schemes and policies that are provided by the government, around $86 \%$ of the respondent are facing problem in mobility, $52 \%$ of women said that they are finding difficult to balance their work life and family life, $67 \%$ are suffered because of not getting proper financial assistance and only $24 \%$ respondent said they are not getting proper support from their family members.

\section{Financial constraints of rural women entrepreneurs}

Finance is the foremost essential for any enterprise. Government has provided various schemes, policies and loans to extent their maximum support for rural women entrepreneurs. Even though many women entrepreneur in the rural informal sector are unaware of these financial assistance, schemes and policies. Most of the rural entrepreneurs are facing problems either when starting their business or during their operation of 
their business enterprise. So the effort taken for rural entrepreneurship development may not reach rural entrepreneurs. Various financial constraints faced by rural women entrepreneurs are shortage of capital, negative attitude of bank towards them, repayment schedule, delay in sanctioning loan, lack of education in financial management

Table: 3

\begin{tabular}{|c|c|c|}
\hline Financial constraints & Number of respondents & Rank \\
\hline 1. Shortage of capital & 17 & 1 \\
\hline 2. Attitude of bank towards them & 12 & 3 \\
\hline 3. $\quad$ Repayment Schedule & 6 & 4 \\
\hline 4. $\quad$ Delay in Sanctioning loan & 15 & 2 \\
\hline $\begin{array}{ll}\text { 5. Lack of education in Financial } \\
\text { management }\end{array}$ & 12 & 3 \\
\hline
\end{tabular}

Table 3 inferred that $81 \%$ are finding shortage of capital investment as a serious constraint, $71 \%$ of respondent feels delay in sanctioning loan as a serious problem, $57 \%$ of respondent feels that negative attitude of banks and lack of financial education are major constraint and $29 \%$ rural women entrepreneurs find very difficult towards rigid repayment schedule.

\section{Social constraints}

Apart from other problem faced by women entrepreneurs in rural informal sector, women also encounter social problems. Various social problems like dual role of women, lack of motivation and family support, male chauvinistic society, lack of exposure and freedom, social security and self-confidence.

Table: 4

\begin{tabular}{|cl|c|c|}
\hline \multicolumn{2}{|c|}{ Social constraints } & Number of respondents & Rank \\
\hline 1. & Dual role of women & 18 & $\mathbf{2}$ \\
\hline 2. & Lack of motivation and support & 15 & $\mathbf{4}$ \\
\hline 3. & Male chauvinistic society & 13 & $\mathbf{5}$ \\
\hline 4. & Lack of exposure and freedom & 16 & $\mathbf{3}$ \\
\hline 5. & Social security & 17 & $\mathbf{1}$ \\
\hline 6. & Lack of self-confidence & 9 & $\mathbf{6}$ \\
\hline
\end{tabular}

From table 4 , it is shown that $86 \%$ of rural women entrepreneurs said that dual role as a major problem., $81 \%$ of respondents are facing social security problems, $76 \%$ said lack of exposure and freedom was the problem, $71 \%$ reported that lack of motivation and support was the constraint, $62 \%$ said that male domination was the biggest challenge and around $43 \%$ said lack of self-confidence was the constraint.

\section{Conclusion}

The contribution of rural women entrepreneurs in the informal sector to the economy was unrecognized till today. The problems and difficulties faced by them are unnoticed.Lack of mobility and capital investment was the major problem of rural entrepreneurs. They are facing various constraints both financially and from the society, Dual role of women increases their work-family conflicts, lack of proper assistance and knowledge acts as the barrier for rural women entrepreneurship to run their business.

This study confesses, rural women entering into entrepreneurship are mainly due to their external circumstances like widow, divorce or gender discrimination. They are using entrepreneurship as a coping strategy to overcome their problems.

Rural women entrepreneurs have various skills towards running a business but the exposure towards business in village is limited. Government should provide proper training and assistance to rural women in order to develop rural entrepreneurship in the informal sector.

\section{References}

[1]. Barhate,G.H and Patgaonkar, M.S. (2012). Rural Women Entrepreneurs in the Informal Sector of India. The IUP Journal of Entrepreneurship Development, Vol.IX, No. 1, 2012.

[2]. Bosma, N. and Harding, R. (2006) Global Entrepreneurship Monitor: GEM 2006 Summary Results, Babson College, Babson Park MA, and London Business School, London, UK.

[3]. Brindley, C. (2005).Barriers to women achieving their entrepreneurial potential."International Journal of Entrepreneurial Behaviour Research 11(2): 144-161.

[4]. Chen, Martha; Carr, M, and Vanek, J. (2004).Mainstreaming informal employment and gender in poverty reduction: A handbook for policymakers and other stakeholders. London: commonwealth secretariat.

[5]. Contribution of the unorganized sector to GDP report of the subcommittee of a NCEUS taskforce: National commission for enterprises in the unorganized sector, 2008. 
[6]. De Bruin, A., Brush, C., \& Welter, F. (2006).Towards building cumulative knowledge on women's entrepreneurship, Entrepreneurship Theory and Practice, 30(5), 585-594.

[7]. Eisenberg, T. D. (2010) "Shattering the equal pay act's glass ceiling". Southern Methodist

[8]. University Law Review, Vol. 63, 2010; U of Maryland Legal Studies Research Paper No. 54

[9]. International labour office (2002a). "Decent work and the informal economy" Geneva: International labour office.

[10]. International labour office (2002b). "Women and Men in the Informal Economy: a statistical picture"” Geneva: International labour office.

[11]. Mbeche, I. (2002), The role of informal sector in Rural development: A case study of carpentry and tailoring in Gucha district, Kenya. Master thesis.Swedish University, Educational planning and Management Depatment.

[12]. Parker, S. C. (2004). The economics of self-employment and entrepreneurship

[13]. Purdy, L. (2005). Women's reproductive autonomy: medicalization and beyond. Journal of Medical Ethics52:287-291.

[14]. Thomas, W.H.(1998), Structural change and the small business sector, paper delivered at the Biannual Conference of the Economic Society of South Africa, 16-17 September, Pretoria, South Africa.

[15]. World Bank, (2003).Importance of SMEs and the Role of public support in promoting SME development.Retrieved on 12-09-2011, http://info.worldbank.org/etools/docs/library/49256/fan.pdf. 